\title{
Geological interpretation of a gravity low in the central part of the Lugian Unit (Czech Republic, Germany and Poland)
}

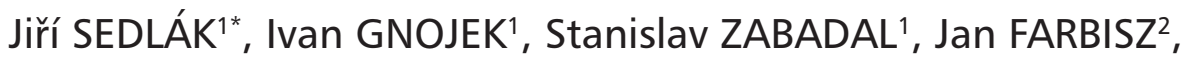 \\ Stefan CWOJDZINSKI ${ }^{3}$, Reiner SCHEIBE ${ }^{4}$ \\ ${ }^{1}$ Miligal, Ltd., Axmanova 531/13, 62300 Brno, Czech Republic; miligal@miligal.cz \\ ${ }^{2}$ Przedsiebiorstwo Badań Geofizycznych, Al. Jaworowa 19, 53-122 Wroclaw, Poland; ejfarbisz@wp.pl \\ ${ }^{3}$ Państwowy Institut Geologiczny, Al. Jaworowa 19, 53-122 Wroclaw, Poland; scwo@pgi.gov.pl \\ ${ }^{4}$ Geophysik GGD mbH, Ehrensteinstrasse 33, Leipzig D-04105, Germany, scheibe@geophysik-ggd.com \\ ${ }^{*}$ Corresponding author
}

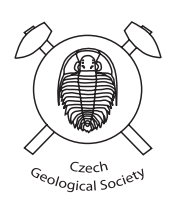

A new detailed map of Bouguer gravity anomalies covers an area of $c .13500 \mathrm{~km}^{2}$ of the Lugian Unit in the Bohemian Massif (Czech Republic, Germany and Poland). It is limited approximately by the towns of Bautzen (NW), Zlotoryja (NE), Červený Kostelec (SE) and Roudnice nad Labem (SW). An extensive gravity low about $120 \mathrm{~km}$ long (W-E) and $40 \mathrm{~km}$ wide $(\mathrm{N}-\mathrm{S})$ is the most remarkable feature in the Bouguer gravity map and the maps derived from it. This central Lugian gravity low (CLGL), is adjacent to the Saxothuringian low in the West but it disappears in the gravity high of the Kaczawa Complex and the Intra Sudetic Basin in the East. Five partial gravity lows, i.e., (A) - Česká Kamenice Low, $(B)$ - Zittau Low, $(C)$ - Jizerské hory Mts. Low, $(D)$ - North Krkonoše/Karkonosze Mts. Low and $(E)$ - Stráž pod Ralskem Low are identified within the CLGL. The lows $(C),(D)$ and $(E)$ were interpreted quantitatively using a gravity modelling, whereas the lows $(A)$ and $(B)$ were evaluated without modelling. The presented gravity cross-sections show that the Cambrian Rumburk granite is the main source of the lows $(A),(B)$ and $(E)$. On the other hand, the Variscan Krkonoše-Jizera granites together with the Cambrian Jizera orthogneisses are the main sources of the lows $(C)$ and $(D)$. Besides that, the sediments of the Czech Cretaceous Basin play an important additional role in the formation of lows $(A)$ and $(E)$ and the Zittau Basin Tertiary sediments are markedly involved in the low $(B)$ amplitude. The gravity crosssections imply that the granite bodies influencing gravity lows can reach a depth of 7 to $10 \mathrm{~km}$. A hidden mafic body situated in the basement of the South Krkonoše Piedmont Late Palaeozoic Basin, producing the gravity high near the town of Vrchlabí, was interpreted to reach a depth of 5 to $6 \mathrm{~km}$ beneath the current surface.

Keywords: gravity anomalies; rock densities; gravity modelling; sources of anomalies; granite rocks-Cadomian, Cambrian, Variscan; Bohemian Massif

Received: 7 February 2007; accepted 6 December 2007; handling editor: M. Štemprok

\section{Introduction}

This contribution represents a geological interpretation of the gravity field in the structurally complicated central part of the Lugian Unit (Fig. 1). A detailed map of the Bouguer gravity anomalies on a scale 1:100 000 and maps derived from it, such as those of regional gravity and horizontal gradient of gravity, were compiled for the large area involving the Eastern Saxony, SW Lower Silesia and North Bohemia. From the administrative point of view it includes the districts of Kamenz, Bautzen and Zittau in Germany, Zgorzelec, Boleslawiec and Jelenia Góra in Poland as well as the districts of Děčín, Česká Lípa, Liberec, Jablonec nad Nisou, Semily and Trutnov in the Czech Republic. The size of the studied area is $150 \mathrm{~km}$ (W-E) by $90 \mathrm{~km}(\mathrm{~N}-\mathrm{S})$, i.e. approximately $13500 \mathrm{~km}^{2}$.

The new detailed map of Bouguer gravity anomalies was compiled using the gravity data from the German ( 10 per cent), Polish ( $\sim 5$ per cent) and Czech ( $\sim 5$ per cent) territories. The dataset of the three countries (ex- ceeding 50000 gravity points) is homogenous as far as the accuracy of measurements, the square density of 4 to 5 measured points per $1 \mathrm{~km}^{2}$ and the data processing methods are concerned. All the data were utilized with the approval of Governmental Authorities of these countries.

\section{Geological setting}

The area of interest comprises the following regional geological structures (Figs 1 and 2; see also the geological map of the Lausitz-Jizera-Krkonoše region by Kozdrój et al. 2001):

- polyphase Lusatian Massif and Lusatian Greywackes making up together the Lusatian Anticlinorium,

- Görlitz Synclinorium,

- Jizera Metamorphic Complex,

- Kaczawa Metamorphic Complex,

- SE part of the North Sudetic Basin (Depression), 


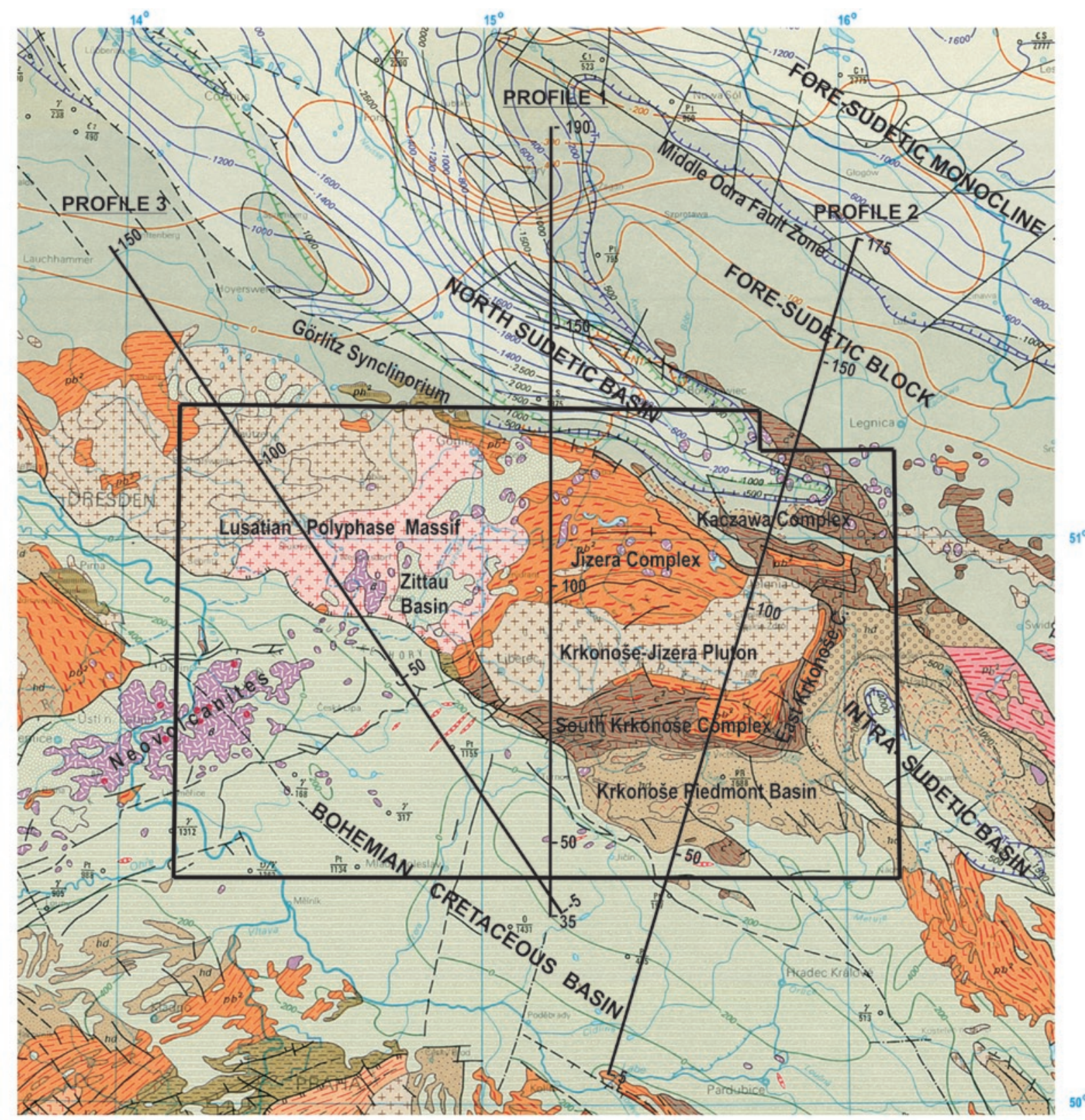

0

50

$100 \mathrm{~km}$
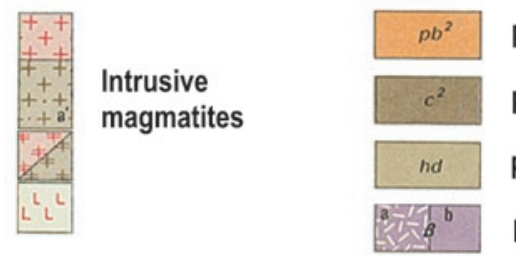

Pre-Variscan metagranites (orthogneisses)

Phyllites to micaschists \& paleovolcanites

Post - tectonic (Neovariscan) basins

magmatites

Neovolcanites

Gray contour $=$ isohypse of a folded basement

Blue contour $=$ stratoisohypse at the Permian/Triassic boundary

Orange contour $=$ stratoisohypse at the base of the Neogene

Green contour $=$ stratoisohypse at the base of the Cretaceous

Black Frame $=$ Area presented on Figures 3, 4, 5 (gravity maps)

Fig. 1 Geological setting of the studied part of the Lugian Unit (modified from the Tectonic map of the Carpathian-Balkan mountain system and adjacent areas, $1: 1000$ 000, Mahel' 1973). Black frame indicates the area of gravimetric maps on Figs 3, 4 and 5. 
- South and East Krkonoše Metamorphic Complex,

- Ještěd Range Unit and Železný Brod Metavolcanic Complex,

- Krkonoše-Jizera Granite Pluton,

- Krkonoše Piedmont Basin,

- Bohemian Cretaceous Basin (Bohemian-Saxonian Cretaceous Basin),

- Zittau Tertiary Basin.

\subsection{Lusatian Anticlinorium}

The Lusatian Anticlinorium consists of two main units - Lusatian Greywackes and Lusatian Granodiorite Massif. The boundary between the two is the SW-NE trending fault system. The Hoyerswerda Fault passing the town of Kamenz (Fig. 2) is one of its branches (Krenz in Kozdrój et al. 2001).

The Lusatian Greywacke Unit builds predominantly the NW part of the anticlinorium (the so-called Kamenz Group). Only three smaller blocks of the Greywacke Unit overlay Cadomian magmatic rocks in the NE (N of Bautzen and Görlitz - Fig. 2). The most extensive Kamenz Group consisting of greywackes, siltstones and argillites, but locally also of conglomerates and black shales, was slightly folded during the Cadomian orogeny (Krenz in Kozdrój et al. 2001). The Machnin Group (named by Chaloupský et al. 1989) outcropping within the W part of the Ještěd Range Unit (W of Liberec, Fig. 2), corresponds probably to the Greywacke Unit (Kozdrój et al. in Kozdrój et al. 2001).

The Lusatian Granodiorite Massif dominates the SE part of the anticlinorium. It involves magmatites of three different ages - Cadomian (Late Proterozoic/Early Cambrian), Early Palaeozoic (Late Cambrian) and Variscan (Kröner et al. 1994; Hammer et al. 1997; Kröner et al. 2001). Two-mica and biotite granodiorites are the main representatives of the Cadomian magmatites; Demitz, Herrnhut, Kamenz and Zawidów biotite granodiorites occur in the area studied. Two-mica granodiorites forming the so-called Pulsnitz Complex were found to be anatexites derived from the Lusatian Greywackes (Ebert 1935).

The Rumburk granite, outcropping in the SE part of the Lusatian Massif, is the main representative of the Cambrian igneous rocks (Kröner et al. 2001).

The biotite granite of Stolpen (near the $\mathrm{S}$ margin of the anticlinorium) and the granites of Arnsdorf and Königshain (on the NE border of the anticlinorium $\mathrm{W}$ and NW of Görlitz) are the only Variscan Lusatian magmatites (Fig. 2).

\subsection{Görlitz Synclinorium}

The Görlitz Synclinorium is a $50 \mathrm{~km}$ long and 4 to $12 \mathrm{~km}$ wide structure at the NE margin of the Lusatian
Granodiorite Massif. Its northern border is formed by the Main Lusatian Fault; the Intra Lusatian Fault limits the synclinorium from the south. The Görlitz Synclinorium is built by a Lower Palaeozoic succession, beginning with Lower Cambrian dolomites, limestones and mafic volcanics and continuing with the Ordovician sandstones, Silurian black shales, Devonian quartzites, greywackes, shales and diabases to Lower Carboniferous flysch sediments. Similar Palaeozoic successions occur in the Kaczawa Region.

\subsection{Jizera Metamorphic Complex}

This unit belongs to the metamorphosed Early Palaeozoic (Cambrian) granodiorites (Kozdrój in Kozdrój et al. 2001). It is mostly considered to be an equivalent of the Rumburk granite but deformed during the Variscan orogeny (Borkowska et al. 1980; Oberc-Dziedzic et al. 2005). However, the relationship between Rumburk granite and Jizera gneiss remain unclear, at least to some authors (Kröner et al. 2001). Augen gneisses, granite gneisses and related metagranites are the most common rock types. Biotite amphibolites are more frequent in the E part of the orthogneiss complex. Three narrow E-W trending belts of micaschists, chlorite-muscovite schists, graphitic quartzites and amphibolites are exposed within the orthogneisses. Tertiary volcanics are concentrated near the $\mathrm{W}$ and $\mathrm{N}$ margins of the complex (Fig. 2).

\subsection{Kaczawa Metamorphic Complex}

The Intra Sudetic Fault separates the Jizera Metamorphic Complex and the eastern part of the Krkonoše-Jizera Pluton (in the S) from the Kaczawa Metamorphic Complex (in the N). It embraces predominantly Early Paleozoic (Cambrian/Ordovician to Lower Carboniferous) volcanosedimentary sequences (Kozdrój in Kozdrój et al. 2001). The Kaczawa Complex also forms the basement of the North Sudetic Basin and continues further to the $\mathrm{N}$ below the Tertiary sediments, reaching as far as the Middle Odra Fault Zone (Fig. 1).

\subsection{North Sudetic Basin}

This depression was opened within the Kaczawa Complex during the Late Palaeozoic times. Its SW margin is limited by the Main Lusatian Fault and the NE border is defined by the Marginal Sudetic Fault (Fig. 2). Upper Carboniferous sediments followed by sequences of Permian age overlie unconformably the Kaczawa metamorphic rocks. The E part of the basin (appearing on the new gravimetric maps presented here) is segmented into several narrow NW-SE trending sub-basins bound by 
almost parallel fault systems. The most common rocks filling the basin are conglomerates, sandstones and siltstones; volcanics are rare in Carboniferous sequences but frequent in the Permian strata. The Late Palaeozoic filling of the basin is followed by Triassic sandstones. The sedimentation was terminated by deposition of Up-

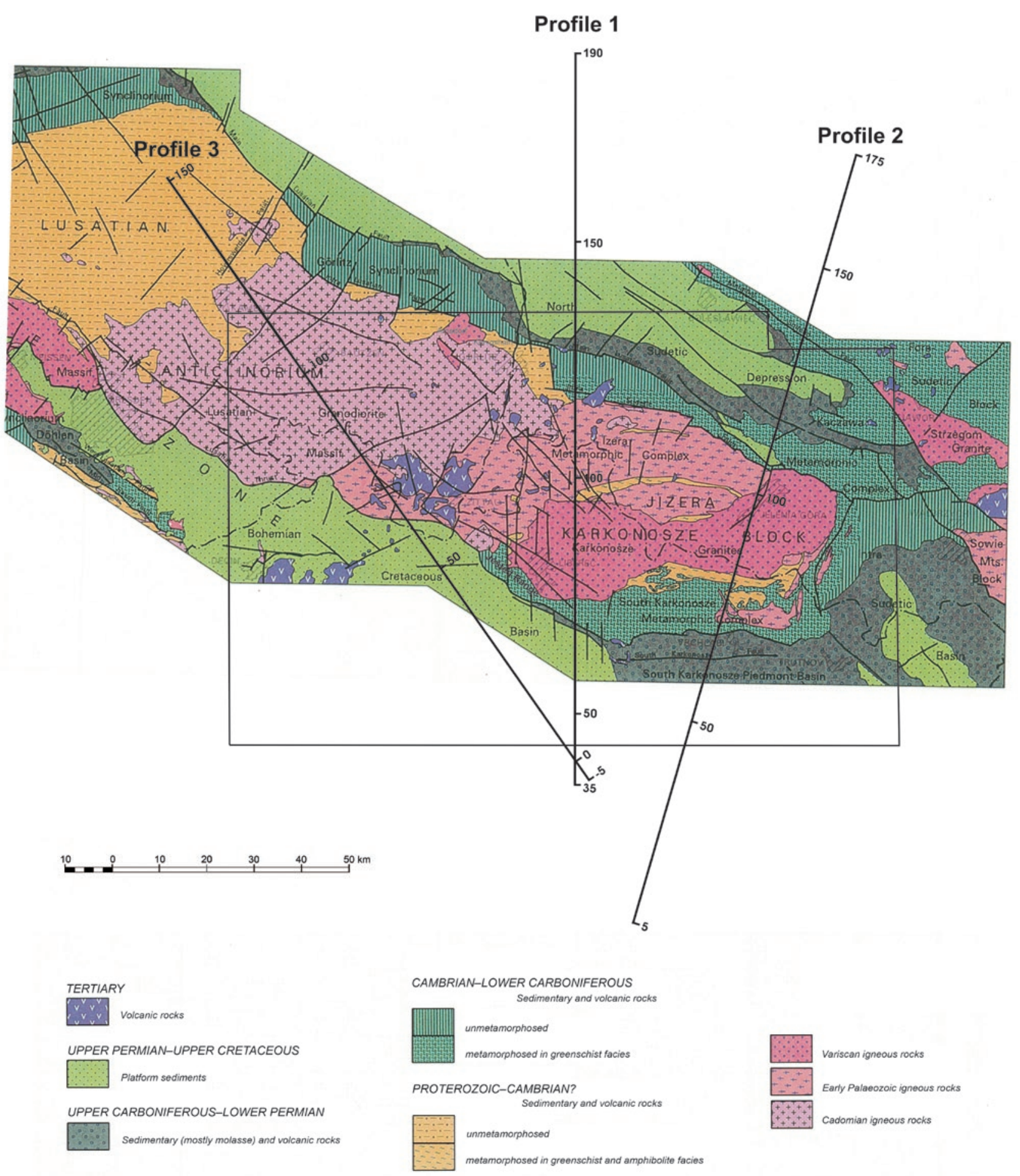

Fig. 2 Tectonic sketch-map Lausitz - Jizera - Karkonosze by Kozdrój et al. (2001), - slightly adapted - with location of the interpretation profiles 1,2 and 3 (shown in the Figs 6, 7 and 8) 
per Cretaceous sandstones, claystones and marls. Tertiary volcanics occur only rarely.

\subsection{South and East Krkonoše Metamorphic Complex}

These are thick sequences of predominantly chloritemuscovite-albite phyllites and micaschists, often alternating with graphite phyllites. The complexes involve intercalations of dolomite marbles, quartzite phyllites, acid volcanic rocks and metabasites. Their stratigraphic span is from Late Proterozoic to Devonian (Kachlík and Patočka 1998; Winchester et al. 2003).

\subsection{Ještěd Range Unit and Železný Brod Metavolcanic Complex}

These are generally complexes of phyllites, with common chlorite-sericite phyllites. Amphibolites and greenschists are very frequent, especially in the Železný Brod Complex. The units were deformed during Variscan orogeny (Kachlík 1997; Kachlík and Kozdrój in Kozdrój et al. 2001).

\subsection{Krkonoše-Jizera Pluton}

The whole Jizerské hory and the $\mathrm{W}$ part of the Krkonoše Mts. in the Czech Republic as well as the large area of the $\mathrm{N}$ slopes of the Karkonosze Mts. in Poland is built by the Krkonoše-Jizera Pluton. Four main types of granites are distinguished - Jizera, Liberec, Tanvald and Fojtka (Klomínský et al. 2004; Žák and Klomínský 2007). The Liberec coarse- to medium-grained biotite granite, which has intruded Lower Palaeozoic metasediments, is the volumetrically prevalent granite type. The Jizera granite, on the contrary, is supposed to form only shallow superficial "blocks" (Klomínský l. c.). The medium-grained muscovite-biotite Tanvald granite borders the western part of the Pluton from the S and the SW (Žák et al. 2006). The Krkonoše-Jizera Pluton and its vicinity are locally cut by dykes of aplites, pegmatites, porphyries, lamprophyres and accompanied by quartz veins.

\subsection{Krkonoše Piedmont Basin}

This basin, Late Palaeozoic in age, has a basement built by the Proterozoic to Early Palaeozoic Krkonoše-Jizera and Zvíčina metamorphic complexes (Martínek in Pešek et al. 2001). The sedimentation began with Upper Carboniferous basal conglomerates, sandstones and breccias. The Permian sequences continued with claystones, marls and intercalated beds of bitumenous limestones. The Permian sedimentation was finished by sandstones and aleuropelites (Pešek et al. 2001).

\subsection{Bohemian Cretaceous Basin}

The Bohemian Cretaceous Basin (Bohemian-Saxonian Cretaceous Basin in the German literature) is situated in the S part of the studied area. Variegated sediments are the oldest products of continental sedimentation before the advance of the sea. The limits between the continental and later marine sedimentation are, admittedly, variable both in time and in lithology. Formations of prevailing shallow sea marls and siltstones and/or of predominant sandstones can be distinguished in the basin. Shallow-sea coarse grained sandstones to conglomerates are typical of the northern marginal part of the basin close to the Lusatian Thrust Fault.

\subsection{Zittau Tertiary Basin}

The Tertiary Zittau Basin is a depression located in the north-eastern continuation of the Ohře (Eger) Rift (Kopecký 1978) reaching the depth of c. $400 \mathrm{~m}$ (Kasińsky 2000). The prevailing eastern part of its basement is built by the Cambrian Rumburk granite, the minor western part is underlain by Cadomian granites. In addition to sediments in the filling, there is a substantial amount of both basic and acid volcanic rocks.

\section{An overview of the gravity anomalies}

\subsection{Gravity field in the central part of the Lugian Unit}

The new Bouguer gravity map of the Lugian Unit (Fig. 3) shows a large interval of gravity anomaly values from $-51 \mathrm{mGal}$ in the Bohemian Cretaceous Basin near Stráž pod Ralskem to $17 \mathrm{mGal}$ in the Lusatian Anticlinorium in the NNW vicinity of the town of Kamenz, i.e. in the so-called Lusatian Gravity High (maximum of BernsdorfKamenz sensu Hänig and Bauer 1993). The mean value of the Bouguer anomaly of the whole area $\left(c .13500 \mathrm{~km}^{2}\right)$ is approximately $-15 \mathrm{mGal}$.

The regional geological structures described in the previous chapter produce a definite and specific response in the gravity field. Synoptical pattern of the gravity responses in geological structure can be seen in the map of the regional gravity anomalies (Fig. 4).

The Lusatian Anticlinorium generates the largest gravity high both in the amplitude and in the areal extent. Its top part exceeds the value of $20 \mathrm{mGal}$ (albeit outside the gravity maps enclosed). The Lusatian Greywacke Unit, Cadomian magmatic rocks and anatexites of the Pulsnitz Complex together with the basic rocks [expected among others by the authors of DECORP 1994 at a deeper $(>7 \mathrm{~km})$ level] are the main components contributing to this gravity high. 


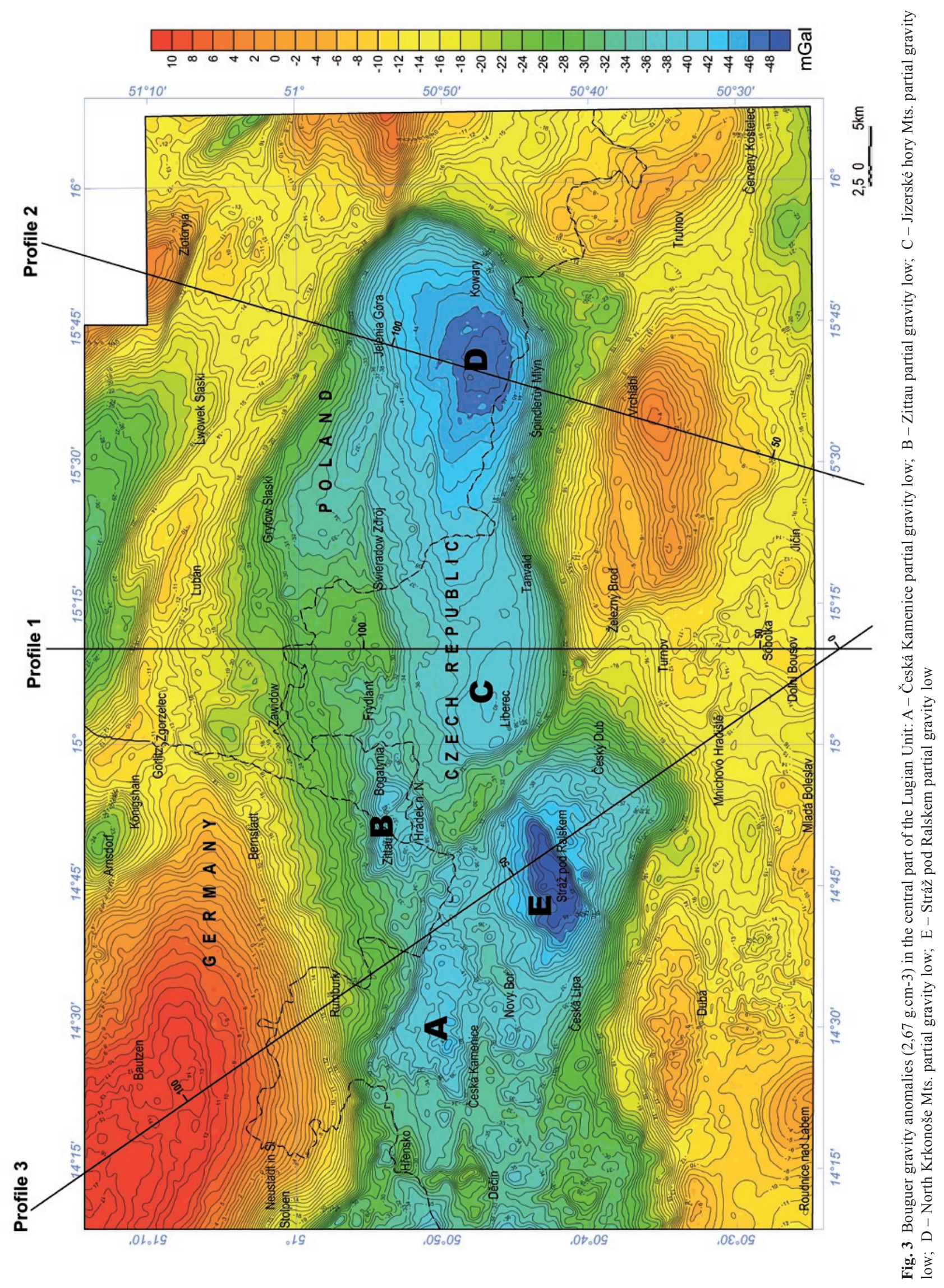




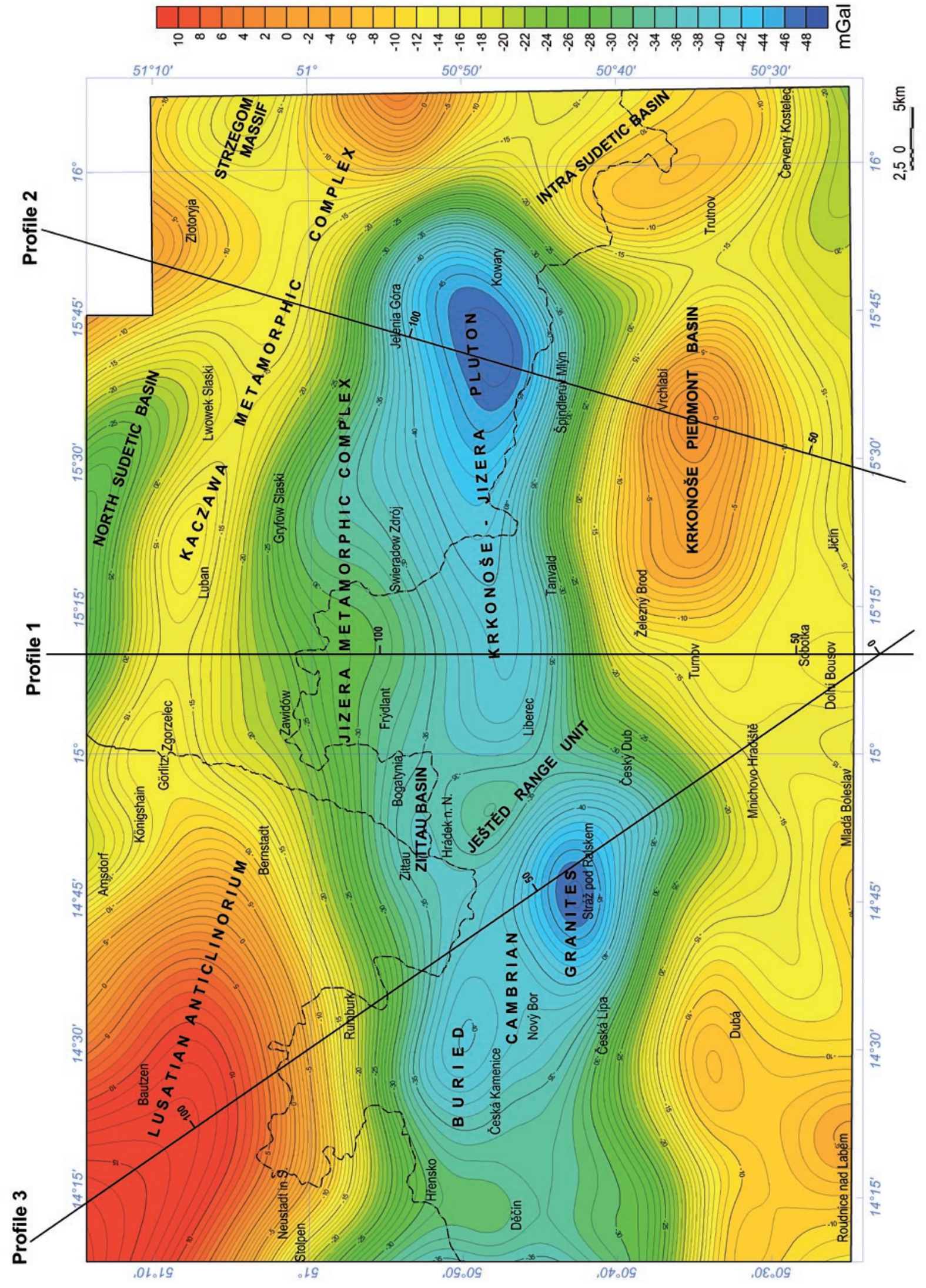


Two exceptional gravity responses - local gravity lows - can be distinguished within the Lusatian Anticlinorium gravity high (Fig. 3). Both are situated at the margins of the anticlinorium. The first one is found at the SW margin and is related to a minor Stolpen granite stock, the second is caused by the small Arnsdorf and Königshain granite bodies cropping out in the NE margin of the anticlinorium (Krentz in Kozdrój et al. 2001). The three said minute granite intrusions are the only representatives of Variscan structures within the Lusatian Anticlinorium. Thus it is possible that not only large Variscan granite masses like the KrkonošeJizera Pluton but also very small Variscan granite bodies could be responsible for the distinct gravity lows in the Lugian Unit.

The Görlitz Synclinorium causes a belt of relatively positive anomalies up to $-10 \mathrm{mGal}$. The Ordovician to Devonian phyllites, schists, quartzites and basic volcanics together with their Proterozoic basement of greywackes and shales are considered to be the sources of this gravity high.

The Jizera Metamorphic Complex mostly represented by various types of orthogneisses is the source of the large "medium gravity low" identified by the range of values from -35 to $-40 \mathrm{mGal}$.

The Kaczawa Metamorphic Complex of the Early Palaeozoic volcano-sedimentary sequences creates a relative gravity high ( -10 to $+10 \mathrm{mGal})$.

The North Sudetic Basin including its SE promontories yields a distinct gravity low. The lowest values of -20 to $-30 \mathrm{mGal}$ are predominantly caused by the youngest Cretaceous filling of the Basin.

The South and East Krkonoše Metamorphic Complex with the Železný Brod Metavolcanic Complex produce relatively positive anomalies of gravity. As they form a country rock to the relatively light Krkonoše-Jizera granites, they are situated in the inclined gravity field. The values systematically increase from $-40 \mathrm{mGal}$ at the contact with the Krkonoše-Jizera Pluton to $-5 \mathrm{mGal}$ at the $\mathrm{S}$ and $\mathrm{E}$ margins of these metamorphic complexes (far from the Pluton).

The Ještěd Range Unit gives a rise to a distinct threshold of relatively high gravity values ( -30 to $-20 \mathrm{mGal}$ ) between the Jizerské hory Mts. partial low $(-40 \mathrm{mGal}$, in the NE) and the deep gravity low of the Stráž pod Ralskem in the marginal part of the Bohemian Cretaceous Basin ( $-50 \mathrm{mGal}$, in the $\mathrm{SW})$.

The Variscan Krkonoše-Jizera Pluton is considered to be the source of a large gravity low ( -40 to $-50 \mathrm{mGal})$ spread over the whole of Jizerské hory Mts., the W part of the Krkonoše Mts. frontier range and the N slopes of the Karkonosze Mts. in Poland.

The area to the $\mathrm{S}$ of the Krkonoše Mts. is occupied by the Late Paleozoic Krkonoše Piedmont Basin, located in a distinct gravity high. However, not the Carboniferous to Permian filling of the basin, but a structure of its crystalline basement is interpreted to be the source of this high.

Sediments of the Bohemian Cretaceous Basin cause in general a decrease of the Bouguer anomalies, from 1 to $12 \mathrm{mGal}$, depending on the thickness (Blížkovský et al. 1981). However, the gravity pattern of the basin is partially due to its depth and partially due to a composition and structure of its basement.

The Tertiary Zittau Basin is responsible for a partial gravity low caused especially by its relatively "light" filling.

Many of fault systems in the studied area are marked by remarkable horizontal gradients of gravity. One of the steepest horizontal gradients of gravity exists in the zone of the Main Lusatian Fault in eastern Saxony. The gradient was termed by Hänig and Bauer (1993), 'Gravity Cliff of the Main Lusatian Fault' (Germ. Schwereflanke des Lausitzer Hauptabbruchs). It continues to the ESE into the $\mathrm{N}$ vicinity of the towns of Zgorzelec and Luban̆ in Poland (Fig. 5). Another steep horizontal gradient is situated in the NE part of the studied area, where the Jerzmanice Thrust Fault creates the Zlotoryja Horst of the Kaczawa Complex towards the NE bay of the North Sudetic Basin.

At the E margin of the area of interest, there is a next steep horizontal gradient in the SE part of the Marginal Sudetic Fault Zone separating the Kaczawa Complex from the Strzegom Massif (Królikowski and Petecki 1995). A similar effect is found on the Intra Sudetic Fault Zone, where the Jizera Metamorphic Complex (mostly of orthogneisses) is in contact with the Early Paleozoic Kaczawa Metamorphic Complex.

In the Czech part of the area, there are remarkable horizontal gradients of gravity on the $\mathrm{N}$ flank of the Bohemian Cretaceous Basin (Fig. 5). One of the most striking gradients follows the Lusatian (Thrust) Fault Zone. Another steep horizontal gradient accompanies the zones of the Stráž, Ploučnice and Český Dub faults found and defined in this basin during exploration works for uranium (Blažek and Zeman eds. 1986-1987).

Besides the principal faults, additional expressive horizontal gradients of gravity are caused by abrupt density differences. As examples could serve the W, S and E exocontacts of the Variscan Krkonoše-Jizera Pluton with their metamorphic country rocks, and the Zittau Basin perimeter, as well. The gravimetric maps (Figs 3 and 5) also clearly show the termination of the so-called "Ohře/ Eger Rift" SW-NE structural trends in the zone of the Main Lusatian Fault and their bending to the "Sudetic" NW-SE directions. This change in the structural trends is apparent mainly in the E surroundings of the town of Zgorzelec. 


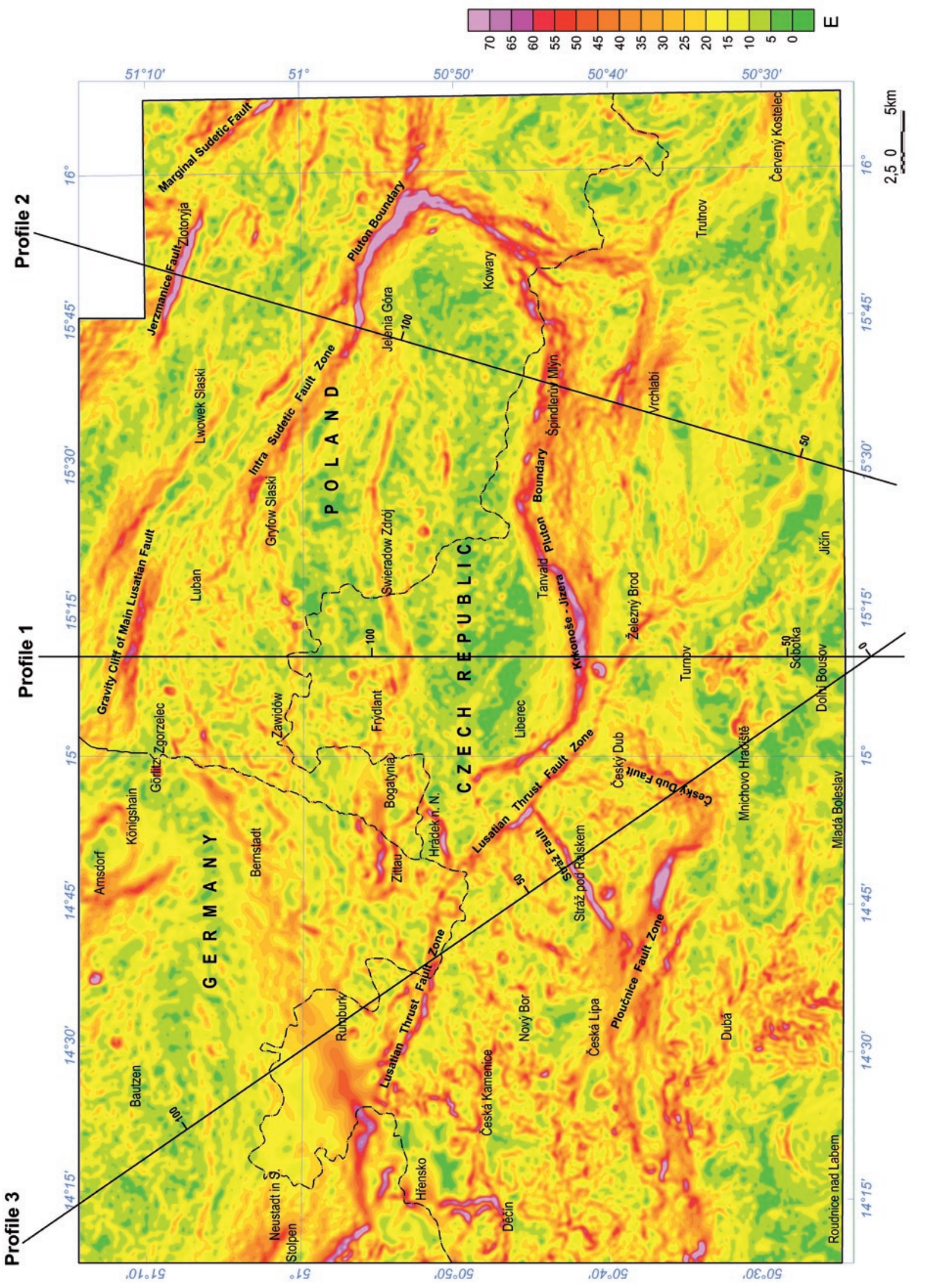




\subsection{Central Lugian gravity low}

The large gravity low in the central part of the Lugian Unit extends $110 \mathrm{~km}$ in the $\mathrm{W}-\mathrm{E}$ and 25 to $40 \mathrm{~km}$ in the $\mathrm{N}-\mathrm{S}$ direction. It can be perceived as an $\mathrm{E}$ continuation of the vast gravity low of the Krušné hory Mts. (Erzgebirge Mts.) described by Hänig and Bauer (1993) and by Bielik et al. (2006). Only a subtle local gravity high situated around the towns of Děčín and Hřensko and reaching mere $-20 \mathrm{mGal}$, separates the two aforementioned regional gravity lows (Figs 3 and 4). The gravity elevation of $-5 \mathrm{mGal}$ pertaining to the Intra Sudetic Basin and a gravity high of $+11 \mathrm{mGal}$ at the SE margins of the Kaczawa Complex terminate the Central Lugian Gravity Low (CLGL) on the E. Five partial gravity lows exceeding $-40 \mathrm{mGal}$ can be delimited within the CLGL (Fig. 3).

(A) Česká Kamenice partial low is situated 3 to $7 \mathrm{~km}$ SSW from the northern margin of the Bohemian Cretaceous Basin. Its extreme value reaches $-42.5 \mathrm{mGal}$. The contour line of $-40 \mathrm{mGal}$ confines a relatively small area stretching in the W-E direction. Sandstones of the Březno Formation with many injections of Tertiary volcanic rocks crop out in this area.

(B) Zittau partial low in the nearest surrounding of Zittau, in the $\mathrm{N}$ vicinity of the Hrádek nad Nisou and in the SW projection of the Polish territory near Bogatynia. The gravity low coincides with the Zittau Tertiary coalbearing Basin and its lowest value is $-40.5 \mathrm{mGal}$.

(C) Jizerské hory Mts. partial low covers the whole area of the mountains forming a circular gravity structure, $22-25 \mathrm{~km}$ in diameter, slightly opened to the E. It has two local minima; the first one $(-40.5 \mathrm{mGal})$ lies in the $\mathrm{N}$ vicinity of the town of Liberec and the second one $(-41 \mathrm{mGal})$ is located at the Extremity of the Jizerské hory Mountains. The whole partial low $(C)$ coincides with the western outcrop of the Variscan Krkonoše-Jizera Pluton.

(D) North Krkonoše Mts. partial low is the largest of the all five partial minima directly arising from the Jizerské hory Mts. partial gravity low. Its deepest part, with values lower than the $-42 \mathrm{mGal}$, covers an area of $31 \mathrm{~km}$ (W-E) by $18 \mathrm{~km}$ (SSW-NNE). The extreme value of -48 $\mathrm{mGal}$ is located at the northern Polish slope of the mountains, some $2.5 \mathrm{~km} \mathrm{~N}$ of the $\mathrm{Czech} /$ Polish border range. The majority of this partial low covers the $\mathrm{N}$ slopes of the Krkonoše Mts. It coincides with the outcropping E part of the Krkonoše-Jizera Pluton and with the exposed part of the Jizera Metamorphic Complex built mostly by orthogneiss.

(E) The Stráż pod Ralskem partial low is the deepest gravity depression of the five mentioned here; its extreme value of $-51.5 \mathrm{mGal}$ is located in the $\mathrm{W}$ vicinity of the town of Stráž pod Ralskem. The anomaly is elongated in the WSW-ENE direction; it reaches the length of
$22 \mathrm{~km}$ at the maximum width of $16 \mathrm{~km}$. The steepest horizontal gradient delimiting this partial low in the SE coincides with the Stráž Fault Zone. The Březno Formation of sandstones, siltstones and claystones crops out in the area of this gravity low. Injections of neovolcanics, mostly basaltic in composition, fill several faults parallel to the Stráž Fault.

\section{Gravimetric modelling and densities of the main rock types}

\subsection{Method}

The method of gravimetric modelling enables us to test the conformity between the calculated gravity response of modelled bodies in a vertical geological cross-section and the gravity effect measured in the field. In addition to the gravity anomalies assessed from the field measurements, densities of rocks, shapes and the depth extent of geological bodies have been considered. To minimize the risk of non-realistic model solutions, the following sources were respected:

- the latest geological maps produced by the Czech Geological Survey,

- data from boreholes, especially of those situated near the line of the cross-section modelled,

- geological maps of different subsurface levels, e.g., the maps of the Bohemian Cretaceous Basin basement substantiated with grids of boreholes drilled by the Uranium Geological Survey (Blažek and Zeman /eds/ 1986-1987; Herzig and Hrušková 1988; DIAMO 1994; Herčík et al. 2003),

- previous unpublished gravimetric models such as those from the North Sudetic Basin and Fore-Sudetic Block in Poland (Bachnacki and Soćko 1984),

- rock density data obtained from outcrops, drill-cores and mines, collected by many individual investigators during last four decades and recently gathered by Ondra and Hanák (2004),

- results of deep-seismic projects, especially in the modelling of some deep levels of cross-sections (DEKORP Research Group B 1994; GFÚ AV ČR 2005).

Some of the granite bodies are undoubtedly the main source of the Lugian gravity minima in all three crosssections, along which was the gravimetric modelling performed. There are two reasons for this statement: a) at least some parts of the granite bodies crop out in the areas of the partial gravity lows; b) certain granite types display densities lower than the mean density of the Earth's crust (2.67 g.cm ${ }^{-3}$, Švancara 2004). Therefore, the gravity modelling focused mainly on determination of the subsurface shape and depth extent of these "light" 
granites. Moreover, special attention has been paid to the position do the geological bodies surrounding the "light" granites as well as of those situated far from such granitic plutons.

The rock density is the crucial input parameter for the gravity modelling. The first information dealing with physical properties of rocks from the Czech part of the Krkonoše Mts. was presented by Ondra and Hanák (1983). Later, Píchová and Červenka (1986) published a comprehensive study of rock densities and magnetic susceptibilities covering almost all crystalline rock types in the area of interest. Densities of sediments filling the Bohemian Cretaceous Basin and their immediate basement were studied by Čejchanová and Racková (1970), and later expanded in a set of reports by Dolanská (1981, 1982, 1983, 1984). The latest density data involving some Czech metamorphic rocks and Tertiary volcanites were gathered in the frame of the field gravimetric survey by Hanák (in Šrámek et al. 2002, and in Sedlák et al. 2003, 2006). The rock densities for the Sudetic and Fore-Sudetic Blocks in Poland were partly taken from the some unpublished gravity modelling undertaken in the Lower Silesian Branch of the Polish Geological Institute (PGI) in Wroclaw, partly also from the article by Żelaźniewicz et al. (1997). The densities pertaining to the Lusatian Anticlinorium were adopted from the study of the DEKORP Research Group B (1994). The velocity models of the seismic lines S01 and S02 realized during Seismic Lithospheric Investigation of Central Europe (SLICE) were also taken into account (GFÚ AV ČR 2005).

The individual geological bodies modelled in gravity cross-sections of the profiles 1, 2 and 3 (Figs 6-8) were characterized by the densities summarised in the Table 1.

\subsection{Geological interpretation of the partial gravity lows}

In this section, the interpretation of the Česká Kamenice and the Zittau partial gravity lows is presented in a qualitative way (i.e., without modelling). On the other hand, the interpretation of the Jizerské hory Mts., North Krkonoše Mts. and Stráž pod Ralskem partial lows is presented in a quantitative way, as an outcome of the gravimetric modelling.

(A) Česká Kamenice partial gravity low $(-42.5 \mathrm{mGal})$ is bound in the $\mathrm{N}$ by the Lusatian Fault that represents the boundary between the Lusatian Massif and the Bohemian Cretaceous Basin. Its $\mathrm{W}$ and $\mathrm{S}$ boundaries seem also to coincide with faults of lower order. Toward the $\mathrm{S}$ of the most apparent part of the Česká Kamenice low there is a less pronounced gravity depression $(-33$ to $-40 \mathrm{mGal}$; only exceptionally reaching values lesser than $-40 \mathrm{mGal}$ at two local minima near Nový Bor).
The boreholes drilled during the uranium exploration campaign in the area of the Česká Kamenice partial gravity low (DIAMO 1994) showed a substantial thickness of Cretaceous sediments (c. 600 to $700 \mathrm{~m}$ ) that were deposited mostly on granites; Permian rocks were rare. Similar or even thicker (700 to $1000 \mathrm{~m}$ ) sequence of Cretaceous sediments was found in the southern and less apparent part of the Česká Kamenice partial gravity low. Its basement is formed by Permian sediments and volcanics (sandstones, siltstones, rhyolites and ignimbrites), which are underlain by a slightly metamorphosed Early Palaeozoic complex.

Indeed, Blížkovský and Novotný (in Blížkovský et al. 1981) obtained one of the highest corrections for the gravity effect of the Cretaceous Basin filling $(-10$ to -12 $\mathrm{mGal}$ ) from the surroundings of the town of Česká Kamenice. The Cretaceous sediments, almost $1 \mathrm{~km}$ thick and having a low density of $c .2 .3 \mathrm{~g} . \mathrm{cm}^{-3}$, are thus considered to be a substantial source of this gravity low. In general, however, the origin of the Česká Kamenice anomaly is explained by the joint response of Cretaceous sediments and relatively light granites (densities of c. 2.64 g. $\mathrm{cm}^{-3}$ ) in footwall. The fact that the part of the gravity low in the W vicinity of Nový Bor is less pronounced seems to be caused by the absence of granites. On the contrary, important role is apparently played by relatively denser Permian sequences below the Cretaceous strata and by the Early Palaeozoic Complex (with densities c. 2.7 g. $\mathrm{cm}^{-3}$ ) in the basement. Thus the negative gravity effect of the Cretaceous sediments, forming a stack thicker than elsewhere, seems to be more than compensated by a positive effect of the Permian and Early Palaeozoic complexes.

(B) Zittau partial gravity low $(-40.5 \mathrm{mGal})$ is composed of two local minima of $<-40 \mathrm{mGal}$ each. The western is located at the SE margin of Zittau, the eastern some 4 to $5 \mathrm{~km} \mathrm{SSW}$ of the town of Bogatynia. The Zittau partial low is predominantly caused by the sediments of the Zittau Tertiary Basin. Its filling consists mostly of unconsolidated lacustrine sediments, six brown coal beds (up to $50 \mathrm{~m}$ thick), various volcanoclastics and volcano-lacustrine sediments. The deepest part of the basin reaches almost $400 \mathrm{~m}$ in depth and coincides with the eastern local gravity minimum. Most of the basin's basement is built by the Rumburk granite topped by a several metres thick weathered (kaolinizied) profile (Kasinski 2000).

Unconsolidated sediments (densities of 2.1-2.3 g. $\mathrm{cm}^{-3}$ ), the brown coal beds $\left(0.8\right.$ to $\left.1.2 \mathrm{~g} . \mathrm{cm}^{-3}\right)$ volcanoclastics and volcano-lacustrine sediments (2.2 to $2.3 \mathrm{~g} . \mathrm{cm}^{-3}$ ), together with the thick weathered crust developed upon the basement granites are the main sources of the Zittau partial gravity low. Moreover, the relatively light Rumburk granites, responsible for a pronounced background 
Tab. 1 Density values of the main rock complexes

(used for the gravimetric modelling of the cross-sections along the profiles 1,2 and 3)

Rock complex

Density $\left[\right.$ g. $\left.\mathrm{cm}^{-3}\right]$

Southern parts of the profiles - mostly crossing the Bohemian Cretaceous Basin:

Main data sources: Čejchanová and Racková (1970), Dolanská (1981-1984), Ondra and Hanák (1983), Sedlák et al. (2003), Ondra and Hanák (2004)

Upper Cretaceous sediments

2.30

Upper Palaeozoic in their basement

$2.50-2.62$

Lower Palaeozoic in their basement

$2.69-2.80$

Magmatites of the (Pre-Variscan) Nový Bydžov Pluton

$2.65-2.67 *$

Proterozoic rocks in a deep basement

$2.85 * *$

Tertiary basaltic rocks

2.90

South Krkonoše Piedmont area

Main data sources: Čejchanová and Racková (1970), Píchová and Červenka (1986), GFÚ AV ČR (2005)

Permian

Upper Carboniferous

Phyllites of the South Krkonoše Metamorphic and the Železný Brod Metavolcanic complexes

Phyllites and mica-schists of the South Krkonoše Metamorphic Complex

2.75

Metabasites of the Železný Brod Metavolcanic Complex

2.86

Devonian to Lower Carboniferous of the Ještěd Range Unit

2.75

Metabasites in the Late Palaeozoic basement

Central parts of the profiles - magmatites and their country rocks

Main data sources: Ondra and Hanák (1983), Píchová and Červenka (1986), Sedlák et al. (2003)

\begin{tabular}{|c|c|}
\hline Variscan granitoids - Tanvald granite & 2.64 \\
\hline- Jizera granite & $2.63-2.66$ \\
\hline - Liberec granite & 2.63 \\
\hline Cambrian granitoids - Jizera orthogneiss & 2.66 \\
\hline- Krkonoše orthogneiss & 2.64 \\
\hline - Rumburk granite & 2.64 \\
\hline
\end{tabular}

Northern parts of the profiles - in Poland and Germany

Main sources of data: Bachnacki and Soćko (1984), Żelaźniewicz et al. (1997), DEKORP Research Group B (1994), GFÚ AV ČR (2005)

North Sudetic Basin - Cretaceous sediments 2.30

$\begin{array}{ll}\text { - Triassic sediments } & 2.45\end{array}$

- Permian (sediments and volcanites) 2.53

- Upper Carboniferous (sediments and volcanites) 2.55

Kaczawa Metamorphic Complex - Early Palaeozoic to Proterozoic 2.80-2.81

- Metabasites $\quad 3.00$

- Boleslawiec granite (Variscan?) $\quad 2.65$

- Proterozoic in a deep basement $\quad 2.85 * *$

Cadomian magmatites (Lusatian Massif) - Zawidów granodiorite 2.73

- Herrnhut granodiorite $\quad 2.71$

- Demitz granodiorite $\quad 2.73$

- Kamenz granodiorite $\quad 2.73$

- anatexites of the Pulsnitz Complex $\quad 2.74$

- basic rocks of a deep basement $2.90 * * *$

Lusatian Graywacke Unit - unmetamorphosed Proterozoic sediments 2.75

Tertiary sediments $2.10-2.20$

* Assumption of the authors based on density data determined on analogous and accessible rock samples

** The density estimate at $2.85 \mathrm{~g} . \mathrm{cm}^{-3}$ is based on the mean bulk densities of 4 samples of siliceous rocks $\left(2.865\right.$ g.cm $\left.{ }^{-3}\right)$ and 9 samples of metatuffs $\left(2.782 \mathrm{~g} . \mathrm{cm}^{-3}\right)$ taken from Proterozoic complex uncovered in the Anna Mine of the Př́ibram District at the depth $>1 \mathrm{~km}$. Moreover, it includes the mean density of 26 samples of palaeobasalts $\left(2.866\right.$ g. $\left.\mathrm{cm}^{-3}\right)$ and 4 samples of metapelites $\left(2.832\right.$ g.cm $\left.{ }^{-3}\right)$ from outcrops of the Kralupy-Zbraslav Group of the Teplá-Barrandian Unit. Weighted arithmetic mean of the mentioned rock collection is $2.845 \mathrm{~g} . \mathrm{cm}^{-3}$.

*** Geophysicists of the DEKORP Research Group B (1994) used the densities of 2.71 to 2.84 g.cm $^{-3}$ (derived from seismic waves velocities) in the depth interval $0-12 \mathrm{~km}$ for the gravimetric modelling in the Lusatian area (NE part of the profile MVE-90). They found that the calculated gravity effect of the modelled cross-section is by 7 to $13 \mathrm{mGal}$ lower than in reality. Consequently, they recommended to use higher densities in this area and reminded the existence of the geomagnetic anomalies present in the region, which ,suggest an emplacement of basic intrusive rocks implying an increase of the densities“. For this reason the density of $2.9 \mathrm{~g} . \mathrm{cm}^{-3}$ was applied in the depth interval $7-10 \mathrm{~km}$ in the N part of the profile 3 (Fig. 8 ). 


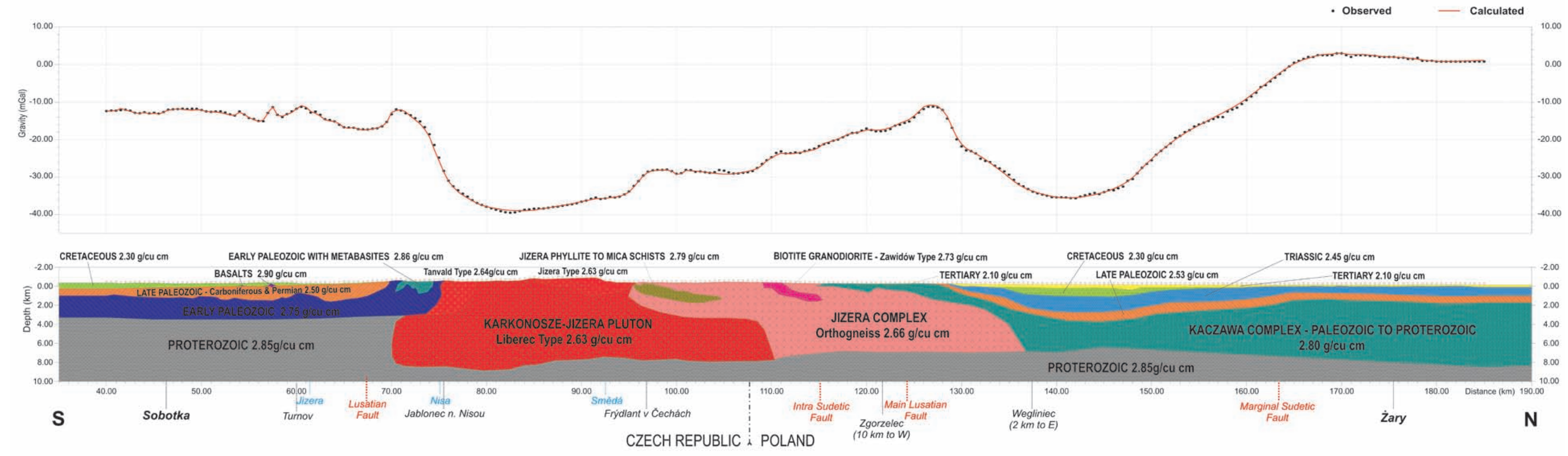

Fig. 6 - Gravity cross-section along the profile 1 Sobotka-Žary

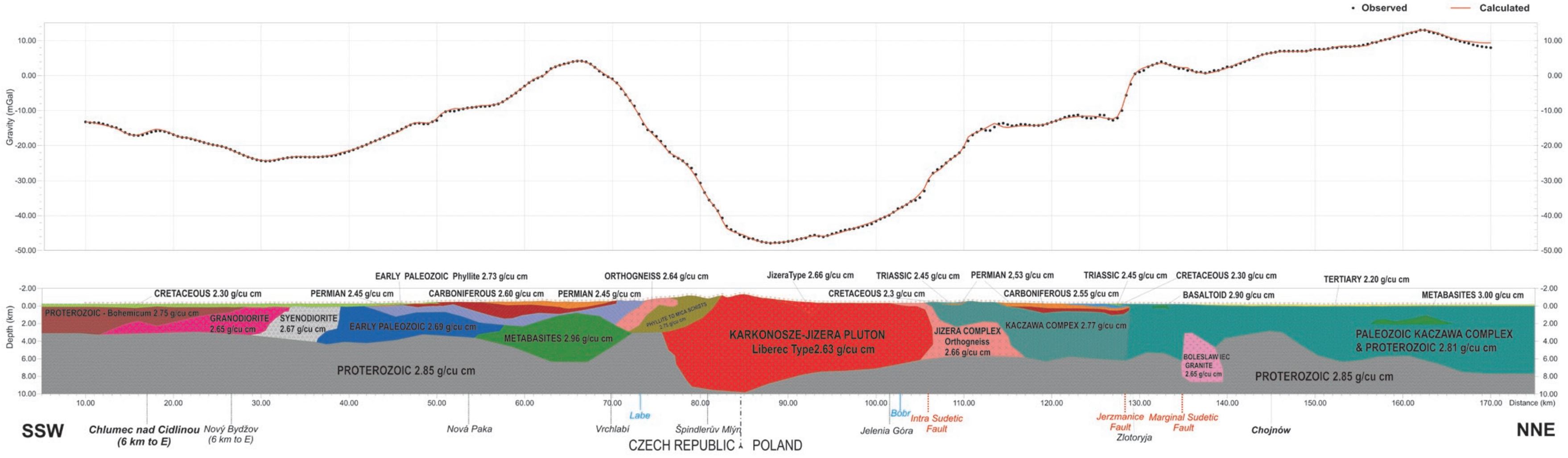


gravity depression ( -25 to $-35 \mathrm{mGal}$ ), further intensify this negative anomaly.

(C) The Jizerské hory Mts. partial gravity low. The gravimetric modelling of the source for this gravity minimum and for the neighbouring gravity structures was performed along the Profile 1 Sobotka-Žary drawn in the azimuth $0^{\circ}$ (Fig. 6). Its beginning is situated in the central part of the Bohemian Cretaceous Basin, in the $\mathrm{W}$ vicinity of Sobotka. The Profile 1 leaves the Cretaceous Basin near Turnov; then it crosses the belt of the Permian rocks and the Železný Brod Metavolcanic Complex. At Jablonec nad Nisou it enters the Jizera part of the Krkonoše-Jizera Pluton. It continues through the Jizera Metamorphic Complex and the Zawidów granodiorite on the Czech/Polish border. Far to the $\mathrm{N}$ it crosses the Kaczawa Metamorphic Complex and the North Sudetic Basin. It ends behind the Marginal Sudetic Fault in the E vicinity of the town of Žary. Its length is $155 \mathrm{~km}$. The starting model was prepared with respect to the results of three boreholes in the Czech Cretaceous Basin (Seletice, Dolní Bousov and Všeň - see Malkovský et al. 1974 and Suk et al. 1991) and one borehole in the North Sudetic Basin (Jagodzin borehole, see Cymerman 2004).

The Jizerské hory partial gravity low is undoubtedly produced by the western part of the Krkonoše-Jizera Pluton, in which dominates the coarse- to mediumgrained porphyritic biotite granite of the Liberec type (mean density of $2.63 \mathrm{~g} . \mathrm{cm}^{-3}$ ). A well balanced gravity model presents this western part of the pluton as a body, southern part of which (near Jablonec nad Nisou) reaches a depth of $\sim 9 \mathrm{~km}$ and northern part extends to a depth of $\sim 8 \mathrm{~km}$. The northern part of the pluton is covered by the Jizera Metamorphic Complex and is expected to continue in depth for further $\sim 15 \mathrm{~km}$ towards the $\mathrm{N}$. This Jizera Metamorphic Complex is mostly built by orthogneisses with a mean density of 2.66 g.cm ${ }^{-3}$. On the Czech territory it represents a wedge-shaped block $\sim 3$ to $4 \mathrm{~km}$ thick, thickness of which increases to $\sim 6-8 \mathrm{~km}$ northwards.

The marked gravity increase from the Jizerské hory Mts. low towards the $\mathrm{N}$ is caused, first of all, by phyllites and micaschists with a density of $2.79 \mathrm{~g} . \mathrm{cm}^{-3}$. Moreover, the block of Cadomian Zawidów biotite granodiorite $\left(2.73{\mathrm{~g} . \mathrm{cm}^{-3}}^{-3}\right)$ seems to be also a major contributor. The partial gravity high in the NE surroundings of Zgorzelec is produced by the Lower Palaeozoic Kaczawa Metamorphic Complex $\left(2.80{\mathrm{~g} . \mathrm{cm}^{-3}}^{-3}\right.$. The Kaczawa gravity high is followed by the partial gravity low created by the North Sudetic Basin. Far to the N, already well behind the Marginal Sudetic Fault, there is a flat gravity elevation triggered by a thick Lower Palaeozoic to Proterozoic complex of the Fore-Sudetic Block buried under the Permian and Triassic cover.

The western part of the Krkonoše-Jizera Pluton is flanked along its S margin by the medium- to coarse- grained biotite to two-mica Tanvald granite with an average density of 2.64 g. $\mathrm{cm}^{-3}$. The gravity model implies that its thickness should be $c .3 .5 \mathrm{~km}$. The increasing gravity values towards the $\mathrm{S}$ are caused by phyllites, micaschists and metabasites of both the South Krkonoše Metamorphic and Železný Brod Metavolcanic complexes. The Upper Palaeozoic sequences were proven below the sediments of the Bohemian Cretaceous Basin. The short-wave gravity anomalies occurring in the $\mathrm{S}$ vicinity of Turnov in the Bohemian Cretaceous Basin can be interpreted as an effect of the local Tertiary basic volcanic bodies.

(D) The North Krkonoše Mts. partial gravity low. The source of this low and the adjoining geologic structures were modelled along the Profile 2 Chlumec nad Cidlinou-Chojnów with the azimuth of $17^{\circ}$ (Fig. 7). Its beginning is located again within the Bohemian Cretaceous Basin in the NW vicinity of Chlumec nad Cidlinou. Further N it enters the South Krkonoše Piedmont Basin and leaves it $\mathrm{N}$ of Vrchlabí. After cutting through a narrow neck of the South Krkonoše Metamorphic Complex, it crosses the Krkonoše-Jizera Pluton along the line Špindlerův Mlýn-Malý Šišák Mt. (state border)-Jelenia Góra. Continuing to the N, it goes across the Kaczawa Mts., then through the SE promontories of the North Sudetic Basin and it ends in the Fore-Sudetic Block covered by Tertiary sediments. The total length of the Profile 2 is $160 \mathrm{~km}$.

The starting model was prepared with respect to the five boreholes in the Czech Cretaceous Basin (Volárna, Dlouhopolsko, Hlušice, Chotělice and Sobčice - see Malkovský et al. 1974), four boreholes in the South Krkonoše Piedmont Basin (Borovnička, Žd'árná, Horní Kalná a Prosečné - see Suk et al. 1991) and four boreholes in the Fore-Sudetic Block (Zagrodno, Piotrowice, Zamienice and Chocianowiec - see Cymerman 2004).

The deep gravity low in the central part of the Profile 2 is undoubtedly connected with the E part of the Krkonoše-Jizera Pluton, mostly represented by the Liberec granite $\left(2.63\right.$ g. $\left.\mathrm{cm}^{-3}\right)$. The gravity model presents the pluton as a body reaching the depth of $11 \mathrm{~km}$. Its thickest part seems to be near the Czech/Polish state border in the N vicinity of Špindlerův Mlýn. Further to the $\mathrm{N}$, the thickness decreases to $7 \mathrm{~km}$ at Jelenia Góra. The maximum width of the pluton body (c. $30 \mathrm{~km}$ in the $\mathrm{N}-\mathrm{S}$ direction) is estimated at the depth level of $4 \mathrm{~km}$.

The Jizera Metamorphic (orthogneiss) Complex, forming the roof of the pluton in the vicinity of Jelenia Góra, is relatively thin - reaching the depth of only several hundreds of metres. However, it continues further to the $\mathrm{N}$ as a 3 to $4 \mathrm{~km}$ thick rock stack underlying the Kaczawa Complex 2 to $3 \mathrm{~km}$ below the surface.

The observed steep gravity increase from Jelenia Góra northwards is evoked by the Kaczawa Metamorphic Complex (mean density of $2.77 \mathrm{~g} . \mathrm{cm}^{-3}$ ). The local interruption 
of a continuous growth in gravity values (between the $113^{\text {th }}$ and the $128^{\text {th }} \mathrm{km}$ of Profile 2) is caused by the SE bay of the North Sudetic Basin filled with Upper Palaeozoic, Triassic and Cretaceous sediments. The shallow gravity depression between the $135^{\text {th }}$ and the $140^{\text {th }} \mathrm{km}$ of the Profile 2 is interpreted as a response to the buried body of the so-called Boleslawiec granite $\left(2.65 \mathrm{~g} . \mathrm{cm}^{-3}\right)$, which intruded the Marginal Sudetic Fault. The existence of this (Variscan?) granite body was originally postulated on the basis of the deep seismic profile GB-2A results (Cwojdzinski et al. 1995). Our interpretation of the gravity field thus provides further indirect evidence for its presence and an estimate of its size and depth. The local elevation of 12 $\mathrm{mGal}$ (the $162^{\text {th }}$ to $163^{\text {th }} \mathrm{km}$ ) indicates a higher proportion of metabasites $\left(3.00\right.$ g. $\mathrm{cm}^{-3}$ ) within the Lower Palaeozoic to Proterozoic basement complex $\left(2.81 \mathrm{~g} . \mathrm{cm}^{-3}\right)$.

The steep growth of gravity values from the Krkonoše-Jizera Pluton low southwards is caused probably by the South Krkonoše Metamorphic Complex of phyllites and micaschists ( 2.73 to $2.75 \mathrm{~g} \mathrm{gcm}^{-3}$ ). The small body of the Krkonoše orthogneiss $\left(2.64 \mathrm{~g} . \mathrm{cm}^{-3}\right)$ produces a local decrease in gravity values.

The positive anomaly of $4 \mathrm{mGal}$ in the South Krkonoše Piedmont Basin is influenced neither by its Upper Palaeozoic filling nor by phyllites in its basement. The real source of this gravity high may be a hidden basic body assumed within the basement by Martínek (in Pešek et al. 2001). The gravity model of the cross-section presented in Fig. 7 shows these basic rocks with a mean density of $2.96 \mathrm{~g} \mathrm{.} \mathrm{cm}^{-3}$ as some $5.5 \mathrm{~km}$ thick and, in the direction of the Profile 2, up to $17 \mathrm{~km}$ large body situated in the $\mathrm{S}$ vicinity of Vrchlabí.

A southward decrease in the Bouguer anomaly values is caused mainly by the Bohemian Cretaceous Basin sediments $\left(2.30\right.$ g. $\left.\mathrm{cm}^{-3}\right)$ and partly by Upper Palaeozoic sequences in their basement. The latter also display relatively low mean densities (e.g., 2.45 g. $\mathrm{cm}^{-3}$ for the Permian and 2.60 g. $\mathrm{cm}^{-3}$ for the Upper Carboniferous sediments). A shallow gravity low (up to $-24 \mathrm{mGal}$ ) is developed in the southern part of the Profile 2 in spite of the uniform depth of the Basin, varying only slightly around $400 \mathrm{~m}$. The anomaly is interpreted as a gravity effect of Pre-Variscan(?) magmatites (granodiorites and syenodiorites of the so-called Nový Bydžov Massif) proved by the Chotělice borehole (Malkovský et al. 1974) in the footwall of the Cretaceous sediments.

(E) The Stráž pod Ralskem partial gravity low. The source of the deepest partial gravity low in the central part of the Lugian Unit and sources of contiguous local gravity anomalies were modelled along the Profile 3 Dolni Bousov-Senftenberg (Fig. 8) drawn in the azimuth $325^{\circ}$. Its southern half passes the Bohemian Cretaceous Basin, beginning near the village of Dolní Bousov. Then it continues into the E vicinity of Mnichovo Hradiště, across Stráž pod Ralskem to the Czech/German border. Subsequently it enters the Lusatian Massif S of Varnsdorf and crosses the Rumburk granite, the Herrnhut granodiorite, anatexites of the Pulsnitz Complex as well as Demitz and Kamenz granodiorites. The profile ends in the Proterozoic sediments of the Kamenz Group, reaching a total length of $150 \mathrm{~km}$.

The starting model was prepared taking into account the results of three "structural" boreholes in the Czech Cretaceous Basin (Dolní Bousov, V̌̌eň and Cetenov - see Malkovský et al. 1974), as well as the boreholes drilled by the Uranium Geological Survey (UP Liberec) within the so-called Stráž and Tlustec blocks of the uranium deposit Hamr na Jezeře (DIAMO 1994).

The deep partial gravity low in the Profile 3 is caused by the combined effect of the granites and Cretaceous sediments. However, the dominant source is believed to be a large granite body - probably of the Rumburk type $\left(2.64 \mathrm{gcm}^{-3}\right)$. The Bohemian Cretaceous Basin sediments $\left(2.30 \mathrm{~g} . \mathrm{cm}^{-3}\right)$ are responsible, due to their variable thickness, only for local fluctuations superimposed on the principal low.

The well-balanced gravity model of the geological cross section along the Profile 3 (Fig. 8) shows the main granite source as a voluminous body reaching a depth of 9 to $10 \mathrm{~km}$ and extending some $60 \mathrm{~km}$ in the NW-SE direction. Besides the Czech/German border area where they actually outcrop, granites are interpreted to build the basement of the $\mathrm{N}$ part of the Bohemian Cretaceous Basin to a distance of $30 \mathrm{~km}$ from the Lusatian Thrust Fault. It means that the southern margins of these granite intrusions may reach (at the depth level of $c .3 \mathrm{~km}$ ) the northern surroundings of Mnichovo Hradiště, i.e., approximately the Český Dub Fault Zone.

The SE part of the gravity cross-section along the Profile 3 pertains to the Bohemian Cretaceous Basin with the thickness of sediments ranging from 200 to $700 \mathrm{~m}$. The shallowest position of the granites - about $200 \mathrm{~m}$ below the Cretaceous strata - was found in the Stráž Fault Zone (the $39^{\text {th }}$ to $44^{\text {th }} \mathrm{km}$ of the Profile 3). North of the Stráž Fault Zone, the Devonian to Lower Carboniferous sediments $\left(2.75 \mathrm{~g} \mathrm{gcm}^{-3}\right)$ underlain by slightly metamorphosed Lower Palaeozoic rocks $\left(2.80 \mathrm{~g} . \mathrm{cm}^{-3}\right)$ were proven by drilling (Rutšek in DIAMO 1994). Permian sediments and volcanic rocks underlain by similar Lower Palaeozoic phyllites were found south of the Stráž Fault Zone. An unknown Proterozoic complex (2.85 g. $\left.\mathrm{cm}^{-3}\right)$, probably related to the Teplá-Barrandian Unit, is assumed at a depth of 5 to $10 \mathrm{~km}$ in the $\mathrm{S}$ part of the Profile 3 .

To the NW from the Rumburk granite, there is a realm of Cadomian rocks. The Pulsnitz Complex of anatectic two-mica granodiorites $\left(2.74 \mathrm{~g} . \mathrm{cm}^{-3}\right)$, locally hidden below Demitz biotite granodiorite intrusion $\left(2.73 \mathrm{~g} . \mathrm{cm}^{-3}\right)$, is modelled as a principal body of the Cadomian struc- 


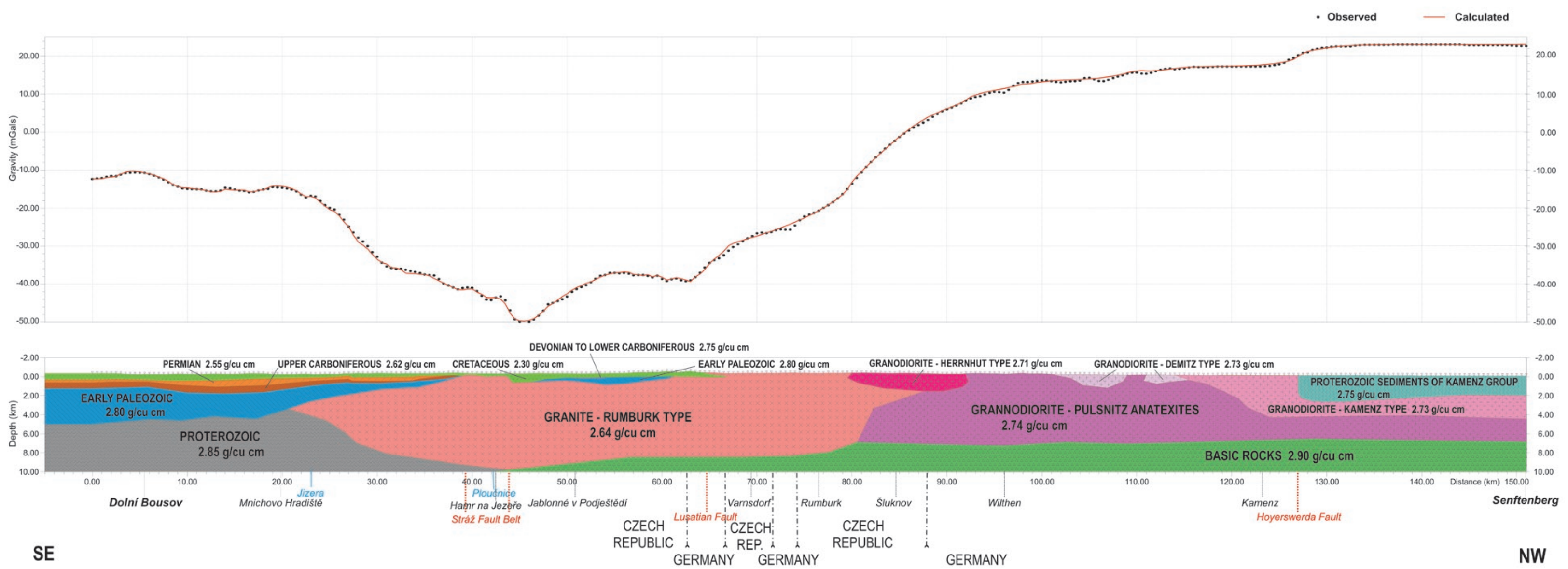

Fig. 8 - Gravity cross-section along the profile 3 Dolní Bousov-Senftenberg 
ture. According to the gravity model, the Kamenz biotite granodiorite $\left(2.73 \mathrm{~g} . \mathrm{cm}^{-3}\right)$ seems to overlap the Cadomian Pulsnitz Complex in the NW.

The envelope of the Cadomian granite intrusions is represented by the Proterozoic sequence of greywackes, siltstones, conglomerates, calc-silicate rocks and black shales of the Kamenz Group (2.75 g.cm $\mathrm{cm}^{-3}$ ). Mafic rocks with a density of $2.90 \mathrm{~g} . \mathrm{cm}^{-3}$ resting at a depth of $7 \mathrm{~km}$ below the Cadomian granites and $9 \mathrm{~km}$ below the Cambrian Rumburk granite are - according to the gravity data - supposed to build a deep fundament of the Lusatian Massif. A similar interpretation of a deeper structure of the Lusatian Anticlinorium is admitted in the report of DEKORP (1994). The presented gravity cross-section also shows that the sequences of the Proterozoic Kamenz Group do not overlie the granites as an envelope of slightly growing thickness but as a 3 to $3.5 \mathrm{~km}$ thick wedge. The steep edge limiting the Kamenz Group in the SE $\left(127^{\text {th }} \mathrm{km}\right.$, Fig. 8) coincides with the fault zone found on the line connecting the towns of Kamenz and Hoyerswerda (Kozdrój et al. 2001).

\section{Conclusions}

The interpretation of gravimetric maps and modelled cross-sections confirmed that all the bodies of Variscan and some of Cambrian granites are the main sources of gravity lows in the central part of the Lugian Unit.

The Variscan Krkonoše-Jizera Pluton creates the vast gravity low covering the whole of Jizerské hory Mts. as well as the $\mathrm{W}$ part of the ridge and the $\mathrm{N}$ slopes of the Krkonoše Mts. Even minor Variscan stocks, such as the Königshain and the Arnsdorf granites in the NE and the Stolpen granite in the SW part of the Lusatian Massif cause distinct partial gravity lows, albeit proportionally small to their limited extent. Similarly, the completely buried Boleslawiec granite, identified originally solely on a basis of a seismic survey and believed to be also Variscan in age, produces a gravity low corresponding to its deep position.

The areal extent of the gravity lows caused by the Variscan granites is significantly magnified by the gravity response of some Cambrian (meta-) granitic rocks. Their main representatives are the Rumburk granite and the Jizera orthogneiss. The large body of the Jizera orthogneiss, bordering the Krkonoše-Jizera Pluton from the N and reaching a depth of $6 \mathrm{~km}$, contributes significantly to the extent of the Jizerské hory Mts. and North Krkonoše Mts. partial gravity lows (C) and (D) (Fig. 3). In case of the Rumburk granite, the relatively low density and vast volume (including the buried part) are important parameters involved in the production of three partial gravity minima: the Stráž pod Ralskem (E), Česká Kamenice (A) and Zittau (B) lows. Local gravity minima superimposed on the extensive low of the Rumburk granite are mostly caused by sudden changes in the thickness of the overlying Cretaceous sediments.

In general, all three gravity cross-sections interpreted in the current work show a considerable depth extent of the granite sources (7 to $11 \mathrm{~km}$ ).

The prominent gravity elevation of the Lusatian Anticlinorium seems to be associated with the extensive dome structure of the two-mica granodiorites - anatexites of the Pulsnitz Complex. The block of mostly unmetamorphosed Proterozoic rocks of the Kamenz Group is the top source of this gravity elevation in the anticlinorium.

A completely buried mafic body situated within the phyllite and micaschist basement is considered to be a dominant source of the gravity high in the area of the Late Palaeozoic Krkonoše Piedmont Basin.

A distinct gravity low is created by the North Sudetic Basin. The Late Palaeozoic and Mesozoic infill with an additional effect of the Tertiary cover are the main sources for this low.

The central part of the Bohemian Cretaceous Basin shown in the southern segments of the profiles 1,2 and 3 yields only slightly fluctuating gravity field. The primary reason for this is only a mildly variable thickness of the Cretaceous infill. Therefore, differences in the gravity field reflect chiefly the structure of its basement. Short wave anomalies are caused by local injections of Tertiary volcanic rocks.

The Zittau Basin gravity low is mostly produced by unconsolidated Tertiary lacustrine sediments, brown coal beds and volcanic-lacustrine sediments. Moreover, this Tertiary fill of low density rests upon relatively light Cambrian granites.

Acknowledgments. The authors gratefully acknowledge the Governmental Authorities of the three Central European countries - Poland, Germany and Czech Republic, i.e. Ministerstwo Środowiska (Ministry of Environment) in Warsaw, Sächsisches Landesamt für Umwelt und Geologie (Saxon Municipal Bureau of Environment and Geology) in Dresden and Ministerstvo životního prostředí (Ministry of Environment) in Prague for the approval to utilize their geophysical data for the across-border geological interpretation.

Our contribution benefited from thorough reviews of V. Blecha (Faculty of Sciences, Charles University, Prague) and of one anonymous reviewer; we express many thanks to both. We are also grateful to V. Janoušek for his language check and careful editorial work.

\section{References}

BACHNACKi S, SoćKo A (1984) Interpretacja geofizycznogeologiczna wyników badań grawimetricznych, magne- 
tycznych, geoelektrycznych, sejsmicznych i satelitarnych dla obszaru Sudetów i bloku przedsudeckiego - cześć zachodnia. Unpublished manuscripts, Archives PBG, Wroclaw

Bielik M, Kloska K, Meurers B, Švancara J, Wybraniec S, CELEBRATION 2000 Potential Field Group (2006) Gravity anomaly map of the CELEBRATION 2000 region. Geol Carpath 57: 145-156

BlažeK J, Zeman J (eds) $(1986,1987)$ Structural geological map of the Czech Republic $1: 200$ 000, sheets 02Ústí nad Labem (1986), 03-Liberec (1987), 13-Hradec Králové (1987). Uranium Geol. Survey, Liberec and Czech Geol. Survey, Prague

Bližzovský M, Friáková O, Kadlec E, Mitrenga P, Novák M, NovotnÝ A, Švancara J (1981) Odkrytá tíhová mapa Českého masivu. Unpublished manuscript, Geofond, Prague.

BorkOWSKa M, HAMEURT J, Vidal P (1980) Origin and age of Izera gneisses and Rumburk granites in Western Sudetes. Acta Geol Pol 30: 121-146

Chaloupský J, Červenka J, Jetel J, Králík F, Líbalová J, Píchová E, Pokorný J, Pošmourný K, Sekyra J, Shrbený O, ŠAlanský K, ŠrámeK J, VÁcl J (1989) Geologie Krkonoš a Jizerských hor. Academia, Prague, pp 1-288

Cwojdziński S, Mlynarski S, Dziewińska L, Jóźwiak W, Zientara P, Baziuk T (1995) GB-2A, pierwszy sejsmiczny profil glebokich badań refleksyjnych (GBS) na Dolnym Ślasku. Przegl Geol 43: 727-737

Cymerman Z (2004) Tectonic Map of the Sudetes and the Fore-Sudetic Block. Paňstwowy Institut Geologiczny, Warsaw

Čejchanová B, Racková H (1970) Fyzikální vlastnosti podloží české křídy. Unpublished manuscript, Geofond, Prague.

DEKORP Research Group (B) (1994) Crustal structure of the Saxothuringian Zone: Results of the deep seismic profile MVE-90 (East). Zeitschrift Geol Wiss 22: 647-771

DIAMO (1994) Přehledná geologická mapa podloží severočeské kř́dy 1:100 000. In: Rutšek J (ed.) Závěrečné zpracování prací uranového průzkumu v české kř́ídové pánvi. Unpublished manuscript, Geofond, Prague

DolAnSKÁ M (1981, 1982, 1983, 1984) Zpráva o fyzikálních vlastnostech hornin v oblasti severočeské křídy, roční etapy 1980,1981,1982,1983. Unpublished manuscripts, Geofond, Prague

EBERT H (1935) Hornfelsbildung und Anatexis im Lausitzer Masiv. Z Dtsch Geol Ges 87: 129-147

GFÚ AV ČR (2005) SLICE, Seismic Lithospheric Investigation of Central Europe. Final report of the Project $\mathrm{VaV} / 630 / 3 / 02$. Unpublished manuscript, Geophysical Institute, Academy of Sciences of the Czech Republic, pp 1-214

HAMmer J, BröCKer M., Kraus M (1997) Alter und geologische Signifikanz von Deformationszonen im östlichen
Teil des Lausitzer Granitoidkompexes. Terra Nostra 97: 62-63

HÄNIG D, BAUER W (1993) Gravimetrische Übersichtskarte des Freistaates Sachsen 1:400 000, Karte der BouguerSchwerestörung. Sächsisches Landesamt für Umwelt und Geologie, Freiberg

Herčí F, Herrmann Z, ValečKa J (2003) Hydrogeology of the Bohemian Cretaceous Basin. Czech Geological Survey Prague, pp 1-91

Herzig J, HrušKová Z (1988) Odvozená strukturně-geologická mapa podloží křídy. Strukturně-tektonická mapa, Izohypsy báze kř́́dy, $1: 200$ 000, listy 03-Liberec a 13-Hradec Králové. In: Prognózní ocenění ČSSR na uran, strukturní patro Kř́da. Unpublished manuscript, Uranium Geological Survey (Uranový Průzkum), Liberec

KАснLík V (1997) Litostratigrafie a stavba železnobrodského krystalinika: výsledek variských tektodeformačních procesů. Zpr geol Výzk v Roce 1996: 30-31

КАснLі́K V, РАтос̌KA F (1998) Cambrian/Ordovician intracontinental rifting and Devonian closure of the rifting generated basins in the Bohemian Massif realms. Acta Univ Carol, Geol 42: 433-441

KAsiŃSKi JR (2000) Geological atlas of the Tertiary lignite-bearing association in the Polish part of the Zittau Basin. Ministerstwo Środowiska and Państowy Institut Geologiczny, Warsaw, pp 1-29

KLomínSKÝ J (ed) (2004) Základní geologická mapa České republiky $1: 25000$ s vysvětlivkami, list 03-143 Liberec. Czech Geological Survey, Prague

KoPeCKÝ L (1978) Neoidic taphrogenetic evolution and young alkaline volcanism of the Bohemian Massif. Sbor geol Věd, Geol 31: 91-107

Kozdró J, Krentz O, Opletal M (eds) (2001) Geological map and Comments on the Geological map Lausitz, Jizera, Karkonosze (without Cenozoic sediments) $1: 100$ 000. Państwowy Instytut Geologiczny, Warsaw

Królikowski C, Petecki Z (1995) Mapa Grawimetryczna Polski, anomalie Bouguera $\left(2,67 \mathrm{Mg} / \mathrm{m}^{3}, 1\right.$ : 75000 . In: Atlas Grawimetryczny Polski, Państwowy Institut Geologiczny, Warsaw

Kröner A, Hegner e, Hammer J, HaAse G, Bielicki KH, Krauss M, Eidam J (1994) Geochronology and Nd-Sr systematics of Lusatian granitoids - significance for the evolution of the Variscan orogen in East-Central Europe. Geol Rundsch 83: 357-376

Kröner A, Jaeckel P, Hegner E, Opletal M (2001) Single zircon ages and whole-rock $\mathrm{Nd}$ isotopic systematics of Early Palaeozoic granitoid gneisses from the Czech and Polish Sudetes (Jizerské hory, Krkonoše Mountains and Orlice-Sněžník Complex). Int J Earth Sci (Geol Rundsch) 90: 304-324

MaheL M (ed) (1973) Tectonic map of the Carpathian-Balkan mountain system and adjacent areas, 1: 1000 000, Bratislava 
Malkovský M, Benešová Z, Čadek J, Holub V, Chaloupský J, Jetel J, Müller V, Mašín, J, TÁsler R (1974) Geologie české křídové pánve a jejího podloží. Czech Geological Survey and Academia, Prague, pp 1-262

Oberc-Dziedzic T, Pin C, Kryza R (2005) Early Palaeozoic crustal melting in an extensional setting: petrological and $\mathrm{Sm}-\mathrm{Nd}$ evidence from the Izera granite-gneisses, Polish Sudetes. Int J Earth Sci (Geol Rundsch) 94: 354-368

ONDRA P, HANÁK J (1983) Hustotní charakteristika hornin krkonošsko-jizerského krystalinika, lužického a krkonošsko-jizerského plutonu. Věst Ústř úst geol 58: 71-77.

ONDRA P, HANÁK J (eds) (2004) Pořádání a využivání geofyzikálních dat pořízených nákladem státního rozpočtu. Registr petrofyziky - etapa 2004. Unpublished manuscript, Geofond, Prague

Pešek J, Jaroš J, Malý L, Martínek K, Prouza V, Spudil J, TÁsLer R (2001) Geologie a ložiska svrchnopaleozoických limnických pánví České republiky. Czech Geological Survey, Prague, pp 1-243

Píchová E, Č́ervenka J (1986) Fyzikální vlastnosti hornin krkonošsko-jizerského krystalinika, lužického, krkonošsko-jizerského plutonu a podkrkonošské permokarbonské pánve. Unpublished manuscript, Geofond, Prague

Sedlák J, Mrlina J, Hanák J, Krejčí Z, Mrázová Š (2003) Gravimetrické mapování $1: 25000$ v oblasti krkonošskojizerského krystalinika. Zpráva za roční výseč prací 2003. Unpublished manuscript, Geofyzika a.s., Brno

Sedlák J, Gnojek I, Zabadal S, Šrámek J, Mrázová Š, KREJČí Z (2006): Gravimetrické mapování $1: 25000$ v oblasti krkonošsko-jizerského krystalinika-závěrečná zpráva. Unpublished manuscript, Ministry of Environment of the Czech Republic, Miligal Ltd., Brno
Suk M, Ďurica D, Obstová V, StaňKová E (1991) Hluboké vrty v Čechách a na Moravě a jejich geologické výsledky. Ministerstvo pro hospodářskou politiku a rozvoj ČR. Gabriel, Prague, pp 1-171

Šrámek J, Mrlina J, Sedlák J, Hanák J, Ondra P, Mrázová Š, KREJČí Z (2002) Gravimetrické mapování $1: 25000$ v oblasti krkonošsko-jizerského krystalinika. Zpráva za roční výseč prací 2002. Unpublished manuscript, Ministry of the Environment of the Czech Republic, Geofond, Prague

ŠvanCARA J (2004) Gravimetrická mapa České republiky. Čs čas fyz 54: 217-220

Winchester JA, PatočKa F, Kachlík V, Melzer M, NawaKowski C, Crowley QG, Floyd PA (2003) Geochemical discrimination of metasedimentary sequences in the Krkonoše-Jizera terrane (West Sudetes, Bohemian Massif): paleotectonic and stratigraphic constrains. Geol Carpath 54: 267-280

Żelaźniewicz A, CWoJdziński S, England RW, Zientara $P$ (1997) Variscides in the Sudetes and the reworked Cadomian orogen: evidence from the GB-2A seismic reflection profiling in southwestern Poland. Geol Quart 41: 289-308

Ž́̇́ J, KLomínskÝ J (2007) Magmatic structures in the Krkonoše-Jizera Plutonic Complex, Bohemian Massif: evidence for localized multiphase flow and small-scale thermal-mechanical instabilities in a granitic magma chamber. J Volcanol Geotherm Res 164: 254-267

Ž́̇́ J, Vyhnálek B, Kabele P (2006) Is there a relationship between magmatic fabrics and brittle fractures in plutons? A view based on structural analysis, anisotropy of magnetic susceptibility and thermo-mechanical modelling of the Tanvald pluton (Bohemian Massif). Phys Earth Planet Inter 157: 286-310

\section{Geologická interpretace tíhového minima v centrální části lugika (Český masiv)}

Podrobná gravimetrická mapa Bouguerových anomálií spojených území severních Čech, východního Saska a polských západních Sudet pokrývající $13500 \mathrm{~km}^{2}$ prezentuje rozlehlé a hluboké tíhové minimum v centrální části lugika (CLGL, obr. 3). Toto minimum v z.-v. směru dosahuje délky $120 \mathrm{~km}$, v s.-j. směru šířky $40 \mathrm{~km}$ a jeho extrémní hodnota nabývá $-51,5 \mathrm{mGal}$. Odvozené gravimetrické mapy regionálních anomálií (obr. 4) a horizontálních gradientů tíže (obr. 5) přehledně vymezují dílčí geologické jednotky a hlavní strukturní prvky tohoto území. V rámci CLGL bylo vyčleněno pět dílčích minim, a to (A) českokamenické dílčí minimum způsobené dílčí depresí křídové pánve a podložními granity lužického masivu, (B) žitavské dílčí minimum vyvolané žitavskou terciérní pánví s přispěním podložních granitů, (C) dílčí minimum Jizerských hor podmíněné převážně granity západní části krkonošsko-jizerského plutonu a v menší míře pak komplexem jizerských ortorul, (D) severokrkonošské dílčí minimum generované téměř výhradně granity krkonošsko-jizerského plutonu a (E) dílčí minimum strážské způsobené převážně kambrickými granity lužického masivu. Kvantitativně interpretované tíhové řezy vedené podél profilů 1, 2 a 3 naznačují dosah granitů krkonošsko-jizerského a lužického plutonu do hloubek 7 až $10 \mathrm{~km}$; kladnou gravimetrickou anomálii v území jihokrkonošského permokarbonu způsobuje bazické těleso, které buduje podloží této podkrkonošské pánve v hloubkovém intervalu 1,5 až $6 \mathrm{~km}$. 
